\title{
Influence of sampling technique and bedding type on the milk microbiota: Results of a pilot study
}

\author{
S. A. Metzger, ${ }^{*}$ L. L. Hernandez, ${ }^{*}$ J. H. Skarlupka,† G. Suen,† T. M. Walker, ${ }^{*}$ and P. L. Ruegg*1,2 \\ *Department of Dairy Science, and \\ †Department of Bacteriology, University of Wisconsin, Madison 53706
}

\begin{abstract}
The objective of this pilot study was to evaluate the influence of sampling technique and exposure to different bedding types on the milk microbiome of healthy primiparous cows. Primiparous Holstein cows $(\mathrm{n}=20)$ with no history of clinical mastitis or monthly somatic cell counts $>150,000$ cells $/ \mathrm{mL}$ were selected for this study. From each enrolled cow, a composite milk sample was aseptically collected from all 4 mammary quarters (individual quarter somatic cell counts $<100,000$ cells / $\mathrm{mL}$ ), 1 individual quarter milk sample was collected using conventional aseptic technique, and 2 individual quarter milk samples were collected directly from the gland cistern using a needle and vacuum tube. All milk samples were cultured using standard milk microbiological techniques and DNA was extracted. Extracted DNA was subjected to PCR and next-generation sequencing for microbiota determination. All samples yielded relatively little total DNA. Amplification of PCR was successful in 45, 40, and $83 \%$ of composite, conventional, and cisternal samples, respectively. Bacteria were successfully cultured from $35 \%$ of composite milk samples but from none of the quarter milk samples collected using conventional or cisternal sampling techniques. Bacterial DNA sequences were assigned to operational taxonomic units (OTU) based on $97 \%$ sequence similarity, and bacterial richness and diversity were determined. Most samples were dominated by low-prevalence OTU and of the 4,051 identified OTU, only 14 were prevalent at more than $1 \%$ each. These included bacteria typically recovered from environmental sources. Chao richness was greatest in composite samples and was 636, 347 , and 356 for composite, conventional quarter, and cisternal milk samples, respectively. Shannon diversity was similar among sample types and ranged from 3.88
\end{abstract}

\footnotetext{
Received November 28, 2017.

Accepted March 9, 2018.

${ }^{1}$ Current address: Department of Animal Science, Michigan State University, East Lansing 48824.

${ }^{2}$ Corresponding author: plruegg@msu.edu
}

(quarter) to 4.17 (composite). Richness and diversity did not differ by bedding type among cisternal samples, but the power of this pilot study was limited due to small sample size. Despite the small sample size, for milk samples collected from the gland cistern, overall bacterial community composition differed among bedding types. These results demonstrate that sampling technique and bedding type may be associated with the microbiota detected in bovine milk, and we suggest that these variables should be considered in designing and reporting studies about the milk microbiota.

Key words: milk microbiome, milk sampling, DNA sequencing, dairy

\section{INTRODUCTION}

The development of high-throughput DNA sequencing has allowed detection of DNA from bacteria that cannot be cultured. Healthy bovine milk was long considered sterile, but recent studies have reported the presence of a microbiota in milk from apparently healthy mammary quarters (Oikonomou et al., 2012; Kuehn et al., 2013; Ganda et al., 2016). Sample collection methods in previous studies about the bovine milk microbiota have varied, making comparisons among studies difficult. This variation has included use of teat sanitizing solutions that conformed with National Mastitis Council recommendations (Kuehn et al., 2013), use of alternative sanitizers (Bhatt et al., 2012), and studies that included producer-collected samples (Oikonomou et al., 2012). All bovine milk microbiota studies reported to date have used milk samples that passed through the teat canal and apex, both of which are known to contain their own microbiota (Braem et al., 2012; Falentin et al., 2016).

The influence of sampling method on results of PCR testing of bovine milk samples has been examined (Hiitiö et al., 2016; Friman et al., 2017). As compared with samples collected using conventional techniques, milk samples collected directly from the gland cistern using a needle and vacuum tube contained fewer bacterial species and required more PCR cycles to detect bacterial 
DNA (Hiitiö et al., 2016) and samples collected with a sterile cannula inserted into the teat canal had reduced numbers of bacterial species and more samples in which no bacteria were detected (Friman et al., 2017). This difference in detected bacterial species presumably occurs because bacterial DNA from the teat canal, teat or udder skin, or environment can be introduced when milk samples are collected manually. Bacteria present on teat skin and within the teat canal may influence which bacteria are detected with culture-independent methods. Moreover, teat skin bacteria have been shown to be associated with bedding type (Rowbotham and Ruegg, 2016). More gram-negative bacteria and streptococci were found on teat skin of cows bedded on manure solids than on sand, as these teats had greater exposure to these types of bacteria. Previous milk microbiota studies have not reported the bedding type of the cows that were studied, which limits understanding of the influence of the cows' exposure to environmental bacteria. The objective of this pilot study was to evaluate the influence of sampling technique and exposure to different bedding types on the milk microbiota of healthy primiparous cows.

\section{MATERIALS AND METHODS}

\section{Cow Eligibility Criteria and Selection}

This study was conducted according to University of Wisconsin-Madison Animal Care and Use Protocol A005753. Cows were housed at the University of Wisconsin Agricultural Research Station, located in Marshfield, Wisconsin. The herd consisted of 127 lactating primiparous cows housed in a single freestall barn containing 4 pens. Each pen contained a different bedding material: deep-bedded new sand, deep-bedded recycled sand, sawdust over foam-core mattresses, or deep-bedded manure solids. Management and bacterial counts of teats and bedding of cows located on this facility have been previously described (Rowbotham and Ruegg, 2016; Guarín et al., 2017). Cows that were 14 to 270 DIM and had not experienced a case of clinical mastitis or had a DHI SCC greater than 150,000 cells $/ \mathrm{mL}$ in their current lactations were eligible to be screened for inclusion in this study $(\mathrm{n}=86)$. All sampling was conducted by university researchers during a single farm visit. Screening of quarter-milk samples for eligibility was performed during the morning milking. Quarter milk samples were collected from each eligible cow at the morning milking, transferred immediately to a local DHI facility (AgSource Milk Analysis Laboratory, Marshfield, WI), and analyzed for SCC (CombiFOSS 6000, Foss Food Technology Corp., Hillerød, Denmark). Quarter-level SCC results were returned within $3 \mathrm{~h}$ and cows with $\mathrm{SCC}<100,000$ cells $/ \mathrm{mL}$ in all 4 quarters were eligible for selection $(\mathrm{n}=67)$. Among eligible cows, 5 from each of the 4 pens were randomly selected for inclusion in the study using a random number generator.

\section{Microbiological Sampling}

Collection of milk samples was completed immediately before the afternoon milking and all aseptic samples were collected by a single researcher. Selected cows $(\mathrm{n}=5)$ from each of the 4 pens were brought to a group pen, restrained in headlocks, and measured with a weight tape. Before collection of any samples, cows were sedated with approximately $0.10 \mathrm{mg} / \mathrm{kg}$ of intravenous xylazine. For all cows, aseptically collected milk samples were collected in the following order: (1) composite milk samples, (2) conventional quarter-milk samples, and (3) cisternal milk samples. After cows were visibly sedated, udders were thoroughly wiped using a clean, dry individual cloth towel to remove gross contamination. Teats were then sanitized according to National Mastitis Council (1999) guidelines. Initially 3 streams of foremilk were manually removed from each teat, then a $0.5 \%$ iodine predip was applied. After 30 $\mathrm{s}$, iodine was wiped off using another clean dry cloth towel. Oxytocin (5 IU) was administered intravenously and a composite milk sample was collected using the following procedures: 3 streams of milk were discarded from one teat, which was then scrubbed with gauze soaked in $70 \%$ isopropanol, and the teat was allowed to dry. Next, 3 streams of milk were discarded again and milk (approximately $10 \mathrm{~mL}$ ) was collected into a sterile sample vial. This process was repeated with the other 3 teats, using the same sample vial.

Individual "extreme aseptic" quarter samples were collected after the composite samples. The sampler put on a new pair of nitrile gloves immediately before discarding another 3 streams of milk and scrubbing the teat with an isopropanol-soaked gauze pad, with emphasis on scrubbing the teat end. The isopropanol was allowed to dry, 3 more streams of milk were discarded, and approximately $40 \mathrm{~mL}$ of milk was collected into a sterile sample vial. Only one teat per cow was sampled using this technique. The first cow was sampled from the right rear, the second cow was sampled from the left rear, the third was sampled from the right front, and the fourth was sampled from the left front. This ordering was repeated until the 20th cow.

Finally, one milk sample from the same enrolled quarter of each cow was collected using cisternal puncture (Hiitiö et al., 2016). A small area at the base of the teat, approximately where the gland cistern is located, was scrubbed with surgical iodine and isopropanol. Af- 
ter the isopropanol dried, a 1-inch $(2.54 \mathrm{~cm})$ Vacutainer needle (BD, Franklin Lakes, NJ) was inserted into the base of the teat pointing upward, such that it would enter the gland cistern. Milk was collected into two 9-mL sterile vacuum blood collection tubes that contained no additive (Greiner Bio-One, Kremsmünster, Austria).

Bedding samples were collected from each pen by one researcher using standardized technique. Briefly, the researcher used gloved hands to collect a handful of visually clean bedding from the back one-third of every third stall in each pen. Samples from within a pen were combined in a clean bucket, and a subsample was transferred to a clean plastic bag with a zip closure. This process was repeated for each pen with clean gloves and buckets.

\section{Microbiological Culturing}

Milk samples were placed on ice, taken to the University of Wisconsin-Madison Milk Quality Laboratory, and frozen at $-20^{\circ} \mathrm{C}$ overnight. The next day, milk was thawed at room temperature and $100 \mu \mathrm{L}$ of milk was inoculated on half of a trypticase soy agar plate containing $5 \%$ sheep blood (BD, Sparks, MD) and half of a MacConkey agar plate (BD, Sparks, MD) and incubated at $37^{\circ} \mathrm{C}$. Plates were checked at 24 and 48 h. If 3 or more colonies of one type were present, one colony was selected and tested for catalase production, coagulase production, mannitol reaction, Gram stain, and morphology. Samples with 3 or more colony types, regardless of number of colonies, would have been considered contaminated, but none were found.

Dry matter content of bedding samples was determined by microwaving 3 to $6 \mathrm{~g}$ of wet bedding for approximately 10 min and $\mathrm{OM}$ was determined by placing 3 to $6 \mathrm{~g}$ of dried bedding in crucibles and heating at $600^{\circ} \mathrm{C}$ for $72 \mathrm{~h}$. For microbiological analysis, $10 \mathrm{~g}$ of wet bedding was suspended in $90 \mathrm{~mL}$ of sterile PBS and agitated manually for $60 \mathrm{~s}$. Bedding particles were allowed to settle for $20 \mathrm{~min}$ and then the supernatant was serially diluted and plated on the following media: MacConkey agar, MacConkey-inositol-carbenicillin agar (MacConkey agar base with $5 \mathrm{~g}$ of myo-inositol/20 $\mathrm{g}$ of MacConkey and $75 \mu \mathrm{g} / \mathrm{mL}$ of carbenicillin as per Hogan et al., 2007), and modified Edwards agar (Oxoid, Basingstoke, UK) with $5 \mathrm{mg} / \mathrm{L}$ of colistin sulfate, 2.5 of $\mathrm{mg} / \mathrm{L}$ of oxolinic acid, and $5 \%$ fetal bovine plasma. Four $10-\mu \mathrm{L}$ inoculations of each dilution $\left(10^{-1}, 10^{-2}\right.$, $10^{-3}$, and $10^{-4}$ ) were pipetted on each plate. Plates were incubated at $37^{\circ} \mathrm{C}$ for $24 \mathrm{~h}$ and the least dilution with countable colony-forming units $(\leq 50 \mathrm{cfu} /$ inoculation). The mean number of colonies per inoculation was calculated for the selected dilution.

\section{DNA Extraction and Quantification}

Four milliliters of whole milk was used for DNA extraction. Samples were centrifuged at $13,000 \times g$ and $4^{\circ} \mathrm{C}$ for $20 \mathrm{~min}$ to produce a pellet, which was extracted with a modified QIAamp DNA Mini Stool Kit (Qiagen, Frederick, MD). Milk fat was removed, Buffer ASL was added, and samples were freeze-thawed $5 \times$ in liquid nitrogen and a $37^{\circ} \mathrm{C}$ water bath and then samples were incubated with lysozyme for $30 \mathrm{~min}$. Samples were then incubated with Proteinase K and Buffer ASL for 10 min before the addition of ethanol. Samples were then added to spin columns, washed with Buffer PE, and eluted with Buffer AE. Extracted DNA was lyophilized and resuspended in $20 \mu \mathrm{L}$ of $\mathrm{H}_{2} \mathrm{O}$ before quantification with a Qubit system (ThermoFisher, Waltham, MA). Real-time quantitative PCR was performed with EvaGreen (Bio-Rad, Hercules, CA) and the following primers for bovine cyclophilin A: forward 5'-CACCGTGTTCTTCGACATCG-3' and reverse 3'-ACAGCTCAAAAGAGACGCGG-5' (Weaver et al., 2017) on a CFX96 Touch Real-Time PCR Detection System (BioRad).

\section{PCR, Microbiota Sequencing, and Sequence Processing}

Samples were amplified using a Phusion polymerase kit (New England BioLabs, Ipswich, MA). The genomic DNA from each sample was amplified using universal bacterial primers for the $16 \mathrm{~S}$ rRNA variable region V4, as previously described (Kozich et al., 2013). A total of $5 \mathrm{ng}$ of diluted DNA, $1 \mu \mathrm{L}$ of $10 \mu M$ forward primer (5'-GTGCCAGCMGCCGCGGTAA-3'), $1 \mu \mathrm{L}$ of 10 $\mu M$ reverse primer (5'-GGACTACHVGGGTWTCTAAT-3'), $6.6 \mu \mathrm{L}$ of Phusion Master Mix, and $\mathrm{H}_{2} \mathrm{O}$ up to $20 \mu \mathrm{L}$ were used in each reaction. The forward and reverse primers each contained unique barcodes to facilitate multiplexing on an Illumina MiSeq (San Diego, CA). All samples underwent PCR with an initial denaturing step at $98^{\circ} \mathrm{C}$ for $30 \mathrm{~s}$, followed by $8 \mathrm{~s}$ of denaturing at $98^{\circ} \mathrm{C}, 20 \mathrm{~s}$ of annealing at $58^{\circ} \mathrm{C}$, and $20 \mathrm{~s}$ of extension at $72^{\circ} \mathrm{C}$. This was repeated for 40 total PCR cycles and finished with a 5 -min extension at $72^{\circ} \mathrm{C}$.

We tested our reagents for contamination by setting up PCR reactions in a biosafety cabinet with new nuclease-free water, primers, and polymerase and no added sample DNA and using the same PCR conditions as used for our samples. Due to our experience with polymerase contamination and previous studies on taq polymerase indicating contamination amplification resulting from PCR cycles >30 (Jervis-Bardy et al., 2015), we also performed PCR without template 
DNA as a negative control. The PCR products were then visualized on an agarose gel; bands were cut out and extracted from the gel with a Zymoclean gel DNA recovery kit (Zymo Research, Irvine, CA). Negative controls for which bands were observed were also cut out and extracted for sequencing. Agarose dissolving buffer was added to gel pieces and gels were incubated at $55^{\circ} \mathrm{C}$ until dissolved. Melted agarose was transferred to a spin column and centrifuged at $10,000 \times g$ for 30 s. The DNA was then washed with wash buffer and eluted with DNA elution buffer into a new sterile microcentrifuge tube. All samples and negative controls were quantified using high-sensitivity Qubit reagents, pooled at equimolar concentrations, and sequenced with $10 \%$ PhiX control DNA on an Illumina MiSeq (Dill-McFarland et al., 2017).

Raw sequences from all samples in fastq format were obtained from the Illumina MiSeq and subjected to cleanup with mothur v1.38.1 (Kozich et al., 2013). Paired-end reads were combined into contigs. Sequences were then screened (maxambig $=0$, maxhomop $=8$, minlength $=200$, maxlength $=500$ ) Identical sequences were grouped using unique.seqs and then aligned to the SILVA 16S rRNA gene reference alignment database (Release 128; Quast et al., 2013). Chimeras were removed using chimera.uchime. The resulting high-quality sequences were then classified using the SILVA database and all nonbacterial sequences were removed (Archaea, Eukaryota, cyanobacteria, and mitochondria). Sequences that appeared only once in the data set were removed and the rest of the sequences were subjected to pairwise distance calculation using dist.seqs. Sequences were assigned to operational taxonomic units (OTU) using cluster.split (method = average, cutoff $=1$ ) at $97 \%$ sequence similarity. The above pipeline was also used to process raw sequence data obtained from our negative controls, and the resulting OTU were removed from our samples before downstream statistical analysis. Good's coverage was calculated for the remaining sample data to determine coverage and the taxonomy of the OTU was determined using the GreenGenes database (August 2013 release; DeSantis et al., 2006). All DNA sequences have been deposited in the National Center for Biotechnology Information Short Read Archive under BioProject ID PRJNA436743 (https://www.ncbi.nlm.nih.gov/ bioproject/436743).

\section{Statistical Analysis}

Descriptive statistics of enrolled cows (cow-level DHIA SCC, daily milk yield, and DIM) and quarters (quarter-level SCC at morning milking) were subjected to an ANOVA by bedding type using PROC MIXED in
SAS 9.4 (SAS Institute Inc., Cary, NC). The experimental unit used for microbiota analysis was milk sample. Chi-squared analysis of PCR band data was done using PROC FREQ in SAS 9.4, whereas DNA yield data and real-time quantitative PCR data were subjected to an ANOVA using PROC MIXED by sample type. For cisternal samples where both duplicate samples had sequencing results, duplicates were averaged and the resulting averages were used for analysis. Chao richness and Shannon diversity indices were generated in mothur (Schloss et al., 2009) and analyzed with a 2-way ANOVA for the effects of bedding and sample type as well as interactions between bedding and sample type using SAS 9.4 PROC MIXED. Canonical discriminant analysis of results of all samples, as well as cisternal samples by bedding type, was performed in SAS 9.4 PROC CANDISC using the relative abundances of the top 15 OTU, and $68 \%$ prediction ellipses were included to cover 1 standard deviation on both axes (Friendly, 2006).

\section{RESULTS}

\section{Characteristics of the Herd and Cows}

Of 127 lactating primiparous cows on the farm, 86 were eligible for screening and 67 passed screening criteria. Cows that met all eligibility criteria were located in pens bedded with new sand $(\mathrm{n}=17)$, recycled sand $(\mathrm{n}=15)$, deep bedded manure solids $(\mathrm{n}=18)$, and mattresses with sawdust $(\mathrm{n}=17)$. Among eligible cows in each pen, 5 were selected from each of the 4 pens for a total of 20 cows. One alternate cow was used because the original cow was kicking even after sedation. Overall, daily milk yield and DIM did not differ $(P>$ 0.50 ) among cows enrolled from different pens and were $35.7 \mathrm{~kg} / \mathrm{d}$ and $151 \mathrm{~d}$, respectively. Quarter-level SCC at the morning milking for the individually sampled quarters did not differ among pens $(P=0.15)$ and had a geometric mean of 15,500 cells $/ \mathrm{mL}$. Cow-level monthly DHI SCC was greatest for cows housed on manure solids (geometric mean: 40,700 cells/mL), intermediate for cows housed on recycled sand (geometric mean: 30,200 cells/mL) and new sand (geometric mean: 23,442 cells/ $\mathrm{mL}$ ), and least for cows housed on sawdust (geometric mean: 20,000 cells/mL; $P=0.013)$.

\section{Microbiological Culturing}

Of composite milk samples $(\mathrm{n}=20), 4$ had nonsignificant microbial growth (1 or 2 bacterial colonies), 2 had growth of non-aureus Staphylococcus spp., and 1 had growth of Corynebacterium spp.; the remaining samples had no visible growth $(\mathrm{n}=13)$. No gram- 
Table 1. Dry matter, OM, and bacterial counts of bedding samples collected from pens of cows enrolled in this study ${ }^{1}$

\begin{tabular}{lcccccr}
\hline Bedding type & $\begin{array}{c}\text { DM } \\
(\%)\end{array}$ & $\begin{array}{c}\text { OM } \\
(\%)\end{array}$ & $\begin{array}{c}\text { Gram-negative } \\
(\mathrm{cfu} / \mathrm{g} \text { of DM) }\end{array}$ & $\begin{array}{c}\text { Coliform } \\
(\mathrm{cfu} / \mathrm{g} \text { of DM) }\end{array}$ & $\begin{array}{c}\text { Klebsiella } \\
\text { (cfu/g of DM) }\end{array}$ \\
\hline Manure solids & 46.2 & 73.5 & $1.50 \times 10^{7}$ & $1.66 \times 10^{6}$ & $3.13 \times 10^{5}$ & $\begin{array}{c}\text { Streptococci } \\
(\mathrm{cfu} / \mathrm{g} \text { of DM) }\end{array}$ \\
Sawdust & 79.0 & 80.8 & $1.33 \times 10^{4}$ & $<5.00 \times 10^{2}$ & $<.10 \times 10^{6}$ \\
New sand & 93.6 & 1.1 & $6.00 \times 10^{3}$ & $<5.00 \times 10^{2}$ & Not detected \\
Recycled sand & 93.3 & 1.6 & $1.26 \times 10^{4}$ & $<5.00 \times 10^{2}$ & Not detected & $2.40 \times 10^{7}$ \\
\hline
\end{tabular}

${ }^{1}$ One composite sample was analyzed per bedding type.

negative bacteria grew from any of the samples and no samples were classified as contaminated. No bacterial colonies were cultivated from any quarter-milk samples collected using extreme aseptic technique $(\mathrm{n}=20)$ or from duplicate quarter-milk samples collected using cisternal puncture $(\mathrm{n}=40)$.

Only samples of manure solids bedding contained large numbers of culturable gram-negative and coliform bacteria, but considerable numbers of streptococci were recovered from all bedding types (Table 1).

\section{Microbiota Analysis}

We used nonculture DNA-based molecular approaches for characterizing the microbiota of our milk samples. A tendency was observed for quantity of DNA extracted from milk samples to differ by sample type $(P=0.073)$, and quantities were $54.7 \mathrm{ng}(2.74 \mathrm{ng} / \mu \mathrm{L})$, $40.1 \mathrm{ng}(2.01 \mathrm{ng} / \mu \mathrm{L})$, and $33.2 \mathrm{ng}(1.66 \mathrm{ng} / \mu \mathrm{L})$ for milk collected using cisternal puncture, composite sampling, and conventional sampling, respectively. Despite addition of a standard amount of DNA (5.0 ng; 0.625 $\mathrm{ng} / \mu \mathrm{L})$ to each $\mathrm{PCR}$ reaction, the proportion of milk samples that resulted in successful PCR amplification was greatest for milk collected using cisternal puncture ( $\mathrm{n}=33 / 40 ; 83 \%)$, as compared with the proportion of milk samples collected using conventional quarter sampling ( $\mathrm{n}=8 / 20 ; 40 \%)$ or composite sampling (n $=9 / 20 ; 45 \% ; P=0.001)$. Of cisternal milk samples that amplified, the distribution by exposure to bedding type was manure solids $(\mathrm{n}=8)$, recycled sand $(\mathrm{n}=8)$, sawdust $(\mathrm{n}=8)$, and new sand $(\mathrm{n}=9)$. Of conventionally collected quarter milk samples that amplified, the distribution by bedding type was manure solids $(\mathrm{n}=2)$, recycled sand $(\mathrm{n}=0)$, sawdust $(\mathrm{n}=2)$, and new sand $(\mathrm{n}=4)$. Of composite milk samples that amplified, the distribution by bedding type was manure solids $(\mathrm{n}=3)$, recycled sand $(\mathrm{n}=1)$, sawdust $(\mathrm{n}=$ $1)$, and new sand $(\mathrm{n}=4)$. The real-time quantitative PCR cycle threshold for detection of bovine DNA in the DNA samples was 28.7 and did not differ by sample type $(P=0.72)$.

Due to the reported low yield of DNA from milk (Kuehn et al., 2013) and greater cycle threshold re- quired for cisternal samples (Hiitiö et al., 2016), we collected duplicate cisternal milk samples because we anticipated that these samples would be more difficult to amplify, thereby requiring larger quantities of milk. We found that this hypothesis was incorrect, as 12 of 20 duplicated samples yielded bands for both samples and 8 of 20 duplicated samples yielded bands for one of the duplicates. When visible amplicon bands were available for both duplicates, we sequenced these duplicates and used both results to obtain average richness, diversity, and sequence values for that mammary quarter.

Microbiota sequencing using an Illumina MiSeq produced 3,350,438 total reads with an average of 40,859 reads per sample. After filtering to remove low-quality sequences, short sequences, and chimeras, a total of $1,895,272$ high-quality reads were retained with an average of 23,113 reads per sample. Clustering of all sequences resulted in a total of 4,051 OTU. The samples were then normalized to 3,500 sequences as 3,500 was the lowest number of sequences present in samples with an acceptable Good's coverage (Weiss et al., 2017). To verify that each sample had sufficient coverage, we calculated Good's coverage and found an average of $97.5 \%$, indicating that we had generated enough sequences per sample. Only 14 of the 4,051 OTU had a sequence abundance greater than $1 \%$ of the total sequences. Of these, an OTU classified to the genus Enhydrobacter (10.8\% of sequences) was most prevalent, whereas 2 other OTU classified to the family of Rhodocyclaceae and genus Janthinobacterium represented 5.8 and $4.7 \%$ of total sequences, respectively (Figure 1). Overall, the proportion of DNA from low-prevalence OTU was $40,46,52$, and $56 \%$ for milk samples collected from cows housed in pens containing manure solids, recycled sand, sawdust on foam-core mattresses, and new sand, respectively (Figure 1). Seven OTU found in negative controls, including the genera Halomonas, Pseudomonas, and Shewanella, were removed as contaminants (Supplemental Figure S1; https://doi.org/10.3168/jds .2017-14212).

In this pilot study, we did not have sufficient sample size to compare richness or diversity based on sample type and bedding type. Chao richness of milk samples did not differ by bedding type $(P=0.34)$. However, 
Manure solids

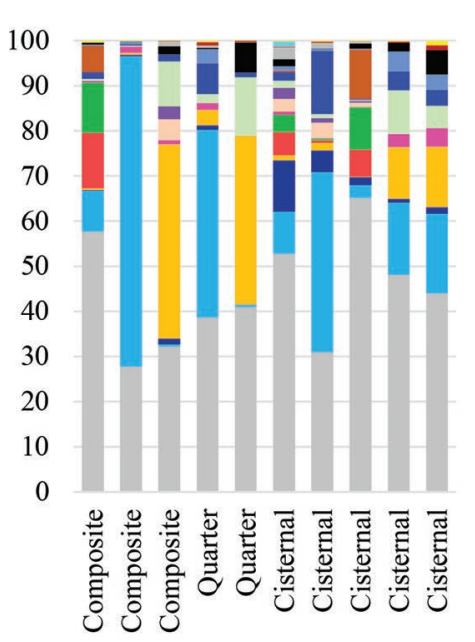

Sawdust

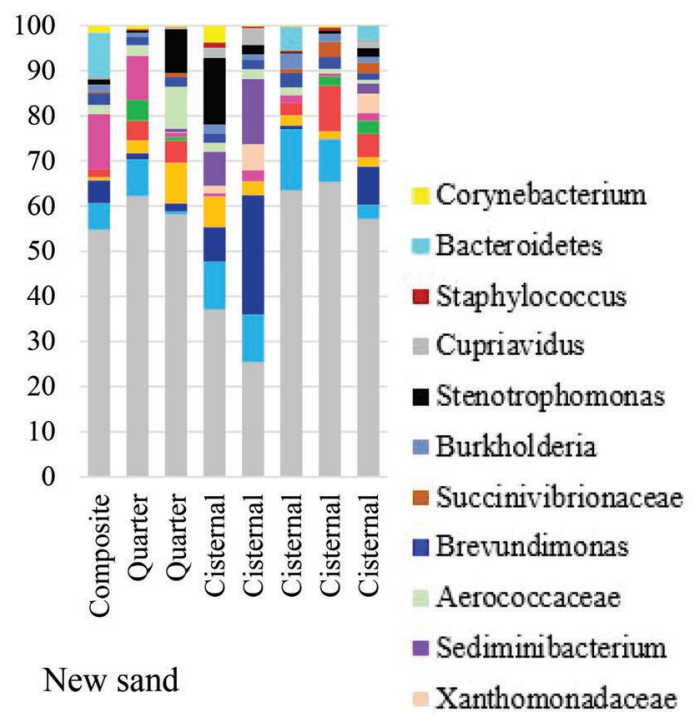

Recycled sand

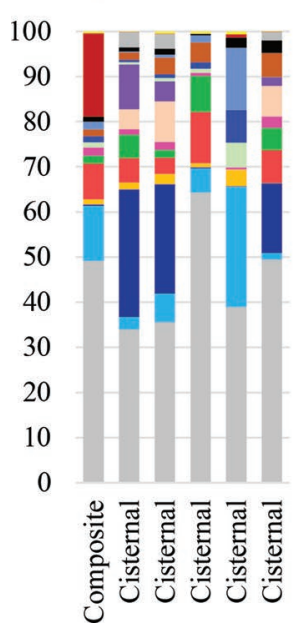

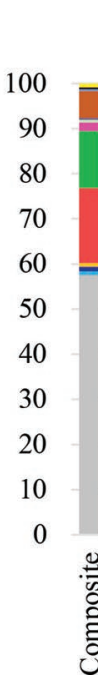

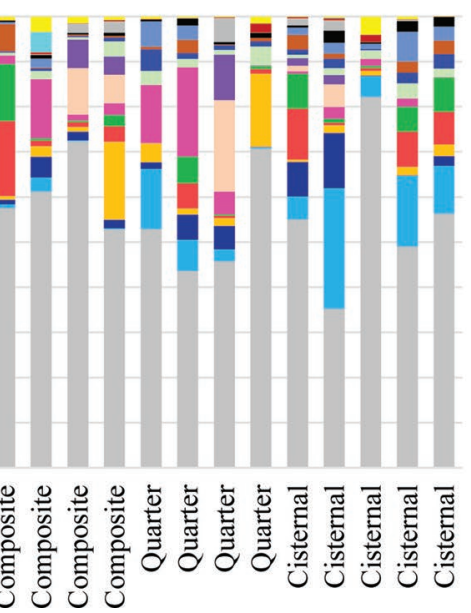

Xanthomonadaceae

-Ellin6075_unclassified

- Succiniclasticum

- Prevotella

Janthinobacterium

- Rhodocyclaceae

Enhydrobacter

- Other

Figure 1. Relative abundances (\%) of operational taxonomic units (OTU) as a percentage of total DNA sequences for milk samples aseptically collected from all 4 quarters of one cow (composite), manually from a single quarter of 1 cow (quarter), or from the cistern of a single quarter of 1 cow with a needle and vacuum tube (cisternal). Cows were housed in 4 pens within one barn each containing a different type of bedding (manure solids, recycled sand, new sand, or sawdust). Color version available online.

when results of milk samples obtained from cows on all bedding types were combined (regardless of sampling technique), richness was greatest in composite samples as compared with quarter-milk samples collected either conventionally or using cisternal puncture (Table 2; $P=0.010)$. Shannon diversity did not differ based on bedding $(P=0.11)$ or sample type (Table $3 ; P=$ 0.49). Canonical discriminant analysis of all samples showed more separation by sample type than bedding type (Figure 2), whereas canonical discriminant analysis performed on only cisternal samples showed that exposure to different bedding types resulted in differences among bacterial community compositions of milk samples despite similar richness and diversity (Figure
3). Cisternal milk samples obtained from cows housed on new sand and recycled sand had similar populations whereas the samples from cows housed on sawdust bedding or manure solids did not overlap.

Sequences classified to the genus Staphylococcus accounted for $18.5 \%$ of the sequences in the composite milk sample from recycled sand bedding (which grew colonies of non-aureus Staphylococcus spp. that were too numerous to count) but did not comprise more than $2.1 \%$ of sequences from any other milk samples. However, a composite sample from a cow housed in the manure solids pen that resulted in the growth of a Corynebacterium spp. at approximately $340 \mathrm{cfu} / \mathrm{mL}$ produced no detectable band after PCR amplification. 
Table 2. Average Chao richness of milk samples aseptically collected from all 4 quarters of 1 cow (composite), from a single quarter of one cow using conventional techniques (quarter), or from the cistern of the same quarter of the same cow using a needle and vacuum tube (cisternal) ${ }^{1}$

\begin{tabular}{|c|c|c|c|}
\hline \multirow[b]{2}{*}{ Bedding type } & \multicolumn{3}{|c|}{ Sample collection method } \\
\hline & $\begin{array}{l}\text { Composite milk } \\
\quad(\mathrm{n}=9)\end{array}$ & $\begin{array}{l}\text { Quarter milk } \\
\quad(\mathrm{n}=8)\end{array}$ & $\begin{array}{l}\text { Cisternal milk } \\
\quad(\mathrm{n}=20)\end{array}$ \\
\hline Manure solids & $601(3)$ & $278(2)$ & $309(5)$ \\
\hline Recycled sand & $488(1)$ & $(0)$ & $475(5)$ \\
\hline Sawdust & $464(1)$ & $349(2)$ & $288(5)$ \\
\hline New sand & $743(4)$ & $393(4)$ & $351(5)$ \\
\hline All bedding types & $636^{\mathrm{a}}(9)$ & $347^{\mathrm{b}}(8)$ & $356^{\mathrm{b}}(20)$ \\
\hline
\end{tabular}

\section{DISCUSSION}

Composite, extreme aseptic quarter-milk, and cisternal milk samples were collected from primiparous dairy cows with low SCC and no history of clinical mastitis to determine the potential influence of sampling method and environmental exposure on the milk microbiota. We sampled only 20 cows because this was a pilot study designed to explore whether these factors may influence the milk microbiota. The small sample size limited our power to detect differences in microbial richness and diversity. Within cisternal samples, neither Chao richness nor Shannon diversity differed by bedding type but statistical power to detect a difference in richness and diversity was 28 and $7 \%$, respectively. To achieve $90 \%$ power for richness and diversity would require 76 and 796 quarter milk samples, respectively (Faul et al., 2007), and our results indicate that a larger study would be beneficial. Despite the lack of power, we were able to identify differences in overall community composition by bedding type. Although the number of OTU and overall evenness of OTU did not differ, OTU were not represented in the same proportions in cisternal samples obtained from cows housed on differ- ent bedding types. These preliminary results indicate that researchers should consider the type of bedding that cows are exposed to as they assess the milk microbiome. When milk samples originate from different farms or pens, researchers should consider the influence of exposure to different bedding types as a potential source of variation. Studies designed to evaluate differences in the milk microbiome based on differing physiological states or infection status should be designed to minimize differing environmental exposures.

The primiparous cows used in our study were chosen because a previous study conducted using cows housed in the same facility reported low SCC and minimal bacterial growth in cultures of quarter milk samples (Rowbotham and Ruegg, 2016) and we wanted to enroll the healthiest possible mammary quarters to minimize the chance that inflammation or infection would influence our results. Cows in this herd are housed in pens that contain different bedding types within the same barn, which provides a unique opportunity to evaluate whether the milk microbiota is associated with bedding type. No studies have examined this relationship, even though housing on different types of bedding is known to be associated with exposure to different distributions

Table 3. Average Shannon diversity of milk samples aseptically collected from all 4 quarters of 1 cow (composite), from a single quarter of 1 cow using conventional techniques (quarter), or from the cistern of the same quarter of the same cow using a needle and vacuum tube (cisternal) $)^{1,2}$

\begin{tabular}{lccc}
\hline & \multicolumn{3}{c}{ Sample collection method } \\
\cline { 2 - 4 } Item & $\begin{array}{c}\text { Composite milk } \\
(\mathrm{n}=9)\end{array}$ & $\begin{array}{c}\text { Quarter milk } \\
(\mathrm{n}=8)\end{array}$ & $\begin{array}{c}\text { Cisternal milk } \\
(\mathrm{n}=20)\end{array}$ \\
\hline Manure solids & $3.32(3)$ & $3.15(2)$ & $3.81(5)$ \\
Recycled sand & $4.36(1)$ & $(0)$ & $4.05(5)$ \\
Sawdust & $4.44(1)$ & $4.56(2)$ & $3.97(5)$ \\
New sand & $4.70(4)$ & $3.90(4)$ & $3.95(5)$ \\
All bedding types & $4.17(9)$ & $3.88(8)$ & $3.94(20)$ \\
\hline
\end{tabular}

${ }^{1}$ The number of samples is in parentheses. Cows were housed in 4 pens within 1 barn; 1 pen contained each bedding type (manure solids, recycled sand, new sand, or sawdust).

${ }^{2}$ Samples within a row did not differ in ANOVA $(P>0.10)$. 


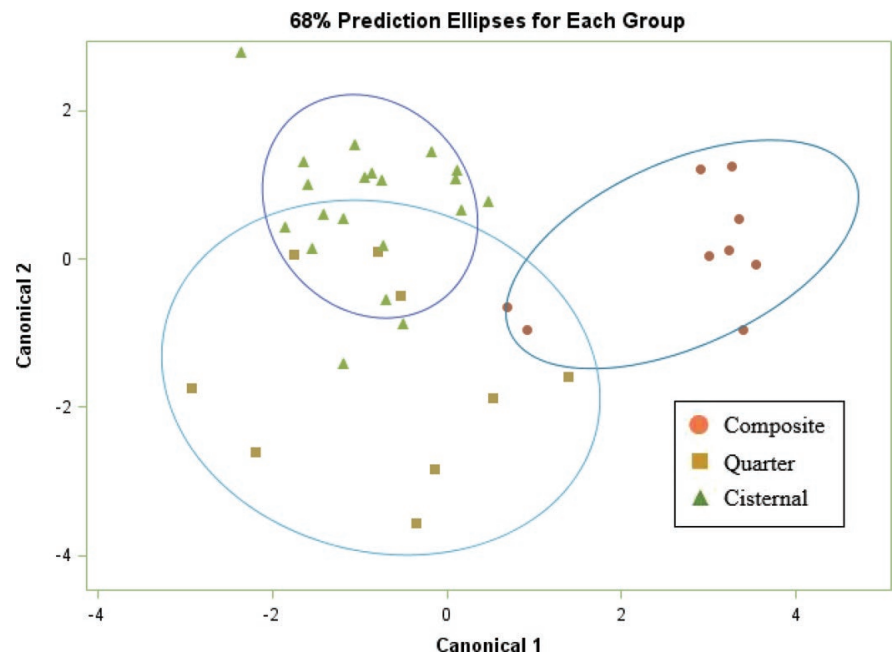

Figure 2. Canonical discriminant analysis of the top 15 operational taxonomic units of composite $(\mathrm{n}=9)$, quarter $(\mathrm{n}=8)$, or cisternal $(\mathrm{n}$ $=20$ ) milk samples with $68 \%$ prediction ellipses around each group. Milk samples were aseptically collected from all 4 quarters of each cow (composite), from a single quarter of each cow using conventional techniques (quarter), or from the cistern of the same quarter of each cow using a needle and vacuum tube (cisternal). All samples (regardless of bedding type) were included. Color version available online.

of potential mastitis pathogens (Hogan et al., 1989; Rowbotham and Ruegg, 2016).

In our study, all milk samples were cultured but only composite milk samples resulted in growth of viable bacteria. Composite milk samples offer the greatest opportunity for isolation of bacteria that may

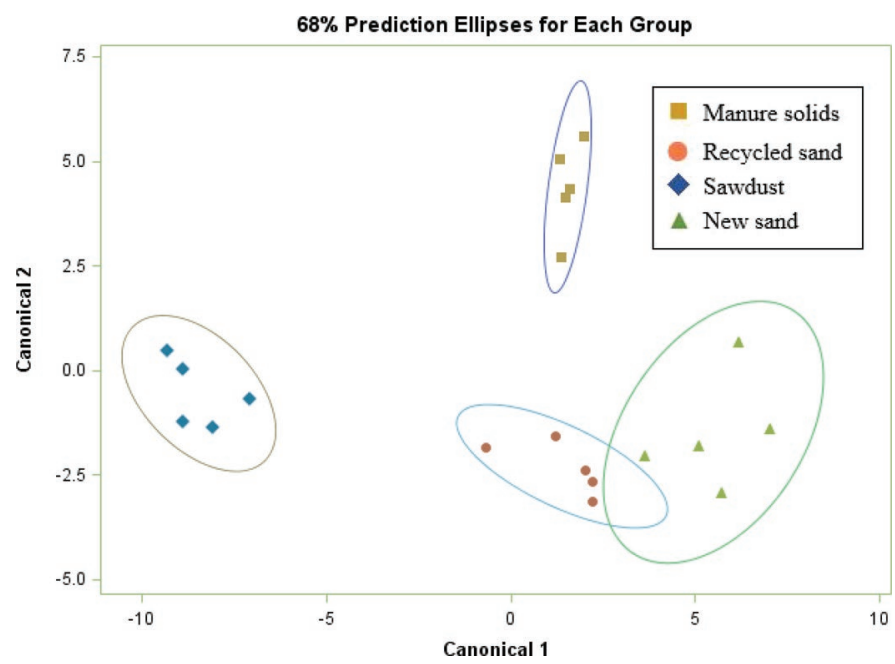

Figure 3. Canonical discriminant analysis of the top 15 operational taxonomic units of milk samples collected using cisternal puncture $(\mathrm{n}=20)$ by bedding type in the cow's pen with $68 \%$ prediction ellipses around each group. Milk samples were collected with needle and vacuum tube from cows housed within a single barn in 4 pens, each with one bedding type: manure solids $(\mathrm{n}=5)$, recycled sand $(\mathrm{n}=5)$, sawdust $(\mathrm{n}=5)$, and new sand $(\mathrm{n}=5)$. Color version available online. have originated from outside the mammary gland, as sampling from all 4 quarters will increase the risk of contamination. Moreover, contamination with external sources of bacterial DNA is probably difficult to avoid when collecting samples in a milking parlor or barn, as bacteria can be present in bedding at millions of colony-forming units per gram of DM (Hogan et al., 1989; Rowbotham and Ruegg, 2016). Although the teat skin is disinfected and scrubbed before sampling (National Mastitis Council, 1999), conventionally collected milk samples must pass through the teat canal. The teat canal may have a different microbiome than milk present in the mammary gland (Falentin et al., 2016) and collecting milk directly from the cistern of the mammary quarter (Hiitiö et al., 2016) allows for bypass of the teat canal. The results of our cisternal samples are based on milk that did not have the opportunity to be contaminated with bacteria present on skin, in the external environment, or in the teat canal. Our results suggest that milk sampled directly from the gland cistern contains bacterial DNA that does not originate in the teat canal and support the need for additional research with larger groups of animals and from more farms to further explore the potential origin and role of these microbial communities.

In our study, we unexpectedly observed that composite and quarter milk samples were less likely to have successful PCR amplification than the cisternal samples. This outcome contrasts with previous work in which cisternal samples had a higher cycle threshold and fewer bacterial species detected with a multiplex PCR (Hiitiö et al., 2016), although DNA yields from the milk samples were not reported in that study. The overall yield of DNA from our cisternal samples tended to be greater than from our quarter or composite samples, but the same total amount of DNA was added to each sample's PCR reaction. Additional research is required to understand why the DNA yield and amplification varied in this way, especially when we had one composite sample with growth in culture that did not have a successful PCR reaction. Previous work has not always found cultured bacteria among the most prevalent OTU after sequencing, and the reason for these discrepancies between culture results and sequencing results is unknown (Oikonomou et al., 2012). The PCR reaction may be inhibited by unaccounted factors in quarter and cisternal samples. The low yield of bacterial DNA from milk samples has commonly been reported in previous studies and has necessitated using 30 (Oikonomou et al., 2012) or 35 PCR cycles; even with 35 cycles, some colostrum samples did not have successful PCR amplication, although the number of failed PCR reactions was not reported (Lima et al., 2017). To address the low DNA yield issue, one group 
performed whole-genome amplification before targeted PCR (Kuehn et al., 2013). A common cycle threshold for detection of bacterial DNA in a commercially available mastitis pathogen PCR kit is 37 cycles (Hiitiö et al., 2016), which is between the 35 cycles that others have used (Lima et al., 2017) and the 40 cycles that we used. Importantly, our samples failed to yield at least $25 \mathrm{ng}$ of DNA, which is typically used to generate PCR products from other samples from cows, such as rumen contents (Dill-McFarland et al., 2017). We had previously attempted to extract bacterial DNA from milk with a bead-beating technique used for feces or rumen contents (Dill-McFarland et al., 2017), but that method had yielded less DNA than the method we used in this study. The use of cisternal samples or alterations in DNA extraction and PCR methodologies are potential areas for improvement for future studies.

Because of low DNA yield from our milk samples, we increased our PCR cycles, and to eliminate the possibility of reagent contamination, we sequenced our negative PCR controls so we could eliminate reagent contaminants from our sequence results as reported previously by Jervis-Bardy et al., (2015). Prior to this study, we had tested polymerase by performing PCR using identical conditions as used in our study. To evaluate the possibility of reagent contamination, we tested new reagents without sample DNA and identified sequences that were consistent with those found in our negative controls. The negative samples from our reagent testing process were consistent with the negative samples that were run parallel with our milk samples. To minimize the potential for environmental contamination, all PCR reactions were performed using a clean biosafety cabinet in a laboratory that specializes in microbiota analysis. Negative control sequences from this study are included with the sample sequences uploaded to the National Center for Biotechnology Information Short Read Archive. Seven OTU that were found in negative controls were removed from sequence results of experimental samples. Of removed OTU, the 3 most prevalent were the genera Pseudomonas, Halomonas, and Shewanella. Pseudomonas has previously been described as a reagent contaminant (Jervis-Bardy et al., 2015) and is a mastitis pathogen that causes rapid increases in SCC and would not likely be found in healthy milk samples such as ours (Bannerman et al., 2005). Halomonas has also been found as a polymerase contaminant (Iulia et al., 2013) but Shewanella was not reported as a contaminant by Iulia et al. (2013) or Jervis-Bardy et al. (2015). Like Pseudomonas, however, Shewanella are water-associated bacteria that grow well in the culture conditions we used (Holt et al., 2005), making the presence of Shewanella unlikely in our milk samples.
The composite milk samples used in our study were the only samples with growth of viable bacteria, and these samples had greater Chao richness than the quarter or cisternal samples. Richness reflects the number of OTU present in a system and diversity measures evenness of OTU. The Shannon diversity of our milk samples was less than other reports, which range from 4.0 (Oikonomou et al., 2014) to 7.5 (Ganda et al., 2016), and our data are closer to the lower end of this spectrum. However, direct comparison of such metrics among studies is difficult as there are many differences in the methodologies used among these studies. For example, we normalized to fewer sequences per sample than other studies, which may contribute to our reduced diversity, and our study used Illumina sequencing whereas others have used 454-based pyrosequencing (Oikonomou et al., 2012; Kuehn et al., 2013) or different DNA extraction methods (Ganda et al., 2016). The low prevalence of DNA sequences from our Staphylococcus- and Corynebacterium-positive samples suggests that the teat skin (Braem et al., 2012; Braem et al., 2013) or teat canal (Falentin et al., 2016) bacteria may have been removed during sanitization or during the forestripping steps. Our sampling protocol included 4 sequential forestripping steps, each of which included removal of 3 streams of foremilk. This is approximately 4 times more milk removed than is normally discarded during routine sampling protocols (National Mastitis Council, 1999). Neither Ganda et al. (2016) nor Lima et al. (2017) cultured milk samples from healthy mammary quarters, which raises uncertainty about whether their samples may have had growth in culture or have been contaminated. These potential sources of variation illustrate the need for development of consistent sampling and laboratory methods for studies of the milk microbiota.

Canonical discriminant analysis of the 15 most prevalent OTU from our cisternal samples revealed differing populations among bedding types, with a large overlap between OTU of samples obtained from cows in pens containing either recycled or new sand. This discrimination based on bedding type was not detectable when all samples, regardless of collection method, were analyzed together. Bacterial exposure of teats differs by bedding type, but some of the most common OTU found in this study are not typically cultured or enumerated in bedding research (Hogan et al., 1989; Rowbotham and Ruegg, 2016). The top OTU we observed included known environmental bacteria from the genus Janthinobacterium, which has been found in soils of cold regions (Shivaji et al., 1991). Organisms from this genus can be grown at $10^{\circ} \mathrm{C}$ on agar plates containing casein (Shivaji et al., 1991) but would not be identified using laboratory methods described for 
culture of dairy cow bedding materials (Hogan et al., 2007). Our study was conducted in Marshfield, Wisconsin, in February 2017, which had temperatures ranging from -19 to $15^{\circ} \mathrm{C}$ (University of Wisconsin-Madison, 2017), similar to conditions in which Janthinobacterium has been identified (Shivaji et al., 1991). Other environmental bacteria we identified included the genus Enhydrobacter, which has been reported to vary in cellulose-degrading capabilities and has been found in plant composts (Premalatha et al., 2015). Bacteria in this genus have been cultured in microaerophilic conditions (Staley et al., 1987), which differ from the aerobic conditions normally found in bedding microbiology (Hogan et al., 2007). We also identified members of the family Rhodocyclaceae, which were some of the most abundant OTU in our study. Members of this family are known to require several weeks of incubation at room temperature for enrichment and growth (Smalley et al., 2015), rather than the $24 \mathrm{~h}$ often used for dairy cow bedding studies (Hogan et al., 2007). Our results suggest that if viable bacteria are present, different microbiological conditions may be required to grow these unusual bacterial taxa from bedding or milk samples. Additionally, viable bacteria would grow very slowly within the mammary gland as the temperature and nutrients present are different from the presumed natural ecosystems or laboratory growth conditions, and the bacteria would be removed frequently during milking.

The Klebsiella, coliforms, and streptococci that grew from our bedding samples are all examples of known mastitis pathogens and are commonly cultured from bedding samples (Rowbotham and Ruegg, 2016). Although present in the bedding, none were cultured from milk samples we collected from the low-SCC, clinically healthy mammary quarters enrolled in our study. We cannot determine in this study whether the DNA from uncultured bacteria we detected in the milk samples were viable, and thus cannot confirm whether the reported microbiota exists as a dynamic community of bacteria within the mammary gland or whether the milk is sterile and contains DNA from nonviable microorganisms that may have been present within phagocytes (Rainard, 2017). However, if some of the bacteria detected in the cisternal samples are indeed alive, the biological significance of bacteria within the mammary gland cistern is as yet unknown.

We conducted this pilot study to determine if further investigation into sampling methods and environmental exposures is needed for future studies on the bovine milk microbiota. Due to the nature of the facility we used, all samples were collected from primiparous cows and the milk microbiota of older animals may differ. Although the inferences that can be drawn from our data set are limited by the small sample size and inclusion of only primiparous cows, our results suggest that both sampling method and bedding type should be considered and reported in future studies of the bovine milk microbiota and efforts should be made to standardize these variables when possible. This is underscored by the unsuccessful PCR amplification of many of the composite and quarter samples, which limits our ability to characterize the microbial communities present in these milk samples. Comparing sampling methods and the associations with bedding type in additional animals would increase our ability to detect differences in the milk microbiota, especially considering the difficulties of amplifying bacterial DNA extracted from milk, and this study highlights important differences in sampling methods that may manifest during sample handling and analysis.

\section{CONCLUSIONS}

The effect of sampling technique and bedding type on the microbiome of bovine milk samples was examined. Milk samples collected via cisternal puncture had the most successful PCR amplification and sequencing and further investigation is required into why the sample type was associated with sequencing success in these low DNA yield samples. Bedding type was associated with the bacterial community composition in cisternal samples, suggesting that bedding should be considered in future milk microbiome studies.

\section{ACKNOWLEDGMENTS}

The authors thank Nancy Esser, Will Cordes, and Sandra Gelsinger of the Marshfield Agricultural Research Station and the Marshfield Agricultural Research Station staff for their assistance with animal handling and sample collection. This project was funded by Agriculture and Food Research Initiative Competitive Grant no. 2013-67015-21348 from the USDA National Institute of Food and Agriculture (Washington, DC).

\section{REFERENCES}

Bannerman, D. D., A. Chockalingam, M. J. Paape, and J. C. Hope. 2005. The bovine innate immune response during experimentallyinduced Pseudomonas aeruginosa mastitis. Vet. Immunol. Immunopathol. 107:201-215. https://doi.org/10.1016/j.vetimm.2005.04 .012 .

Bhatt, V. D., V. B. Ahir, P. G. Koringa, S. J. Jakhesara, D. N. Rank, D. S. Nauriyal, A. P. Kunjadia, and C. G. Joshi. 2012. Milk microbiome signatures of subclinical mastitis-affected cattle analysed by shotgun sequencing. J. Appl. Microbiol. 112:639-650. https://doi .org/10.1111/j.1365-2672.2012.05244.x.

Braem, G., S. De Vliegher, B. Verbist, M. Heyndrickx, F. Leroy, and L. De Vuyst. 2012. Culture-independent exploration of the teat apex microbiota of dairy cows reveals a wide bacterial species diversity. Vet. Microbiol. 157:383-390. https://doi.org/10.1016/j .vetmic.2011.12.031. 
Braem, G., S. De Vliegher, B. Verbist, V. Piessens, E. Van Coillie, L. De Vuyst, and F. Leroy. 2013. Unraveling the microbiota of teat apices of clinically healthy lactating dairy cows, with special emphasis on coagulase-negative staphylococci. J. Dairy Sci. 96:1499-1510. https://doi.org/10.3168/jds.2012-5493.

DeSantis, T. Z., P. Hugenholt, N. Larsen, M. Rojas, E. L. Brodie, K. Keller, T. Huber, D. Dalevi, P. Hu, and G. L. Andersen. 2006. Greengenes, a chimera-checked 16S rRNA gene database and workbench compatible with ARB. Appl. Environ. Microbiol. Environ. Microbiol. 72:5069-5072. https://doi.org/10.1128/AEM.03006-05.

Dill-McFarland, K. A., J. D. Breaker, and G. Suen. 2017. Microbial succession in the gastrointestinal tract of dairy cows from 2 weeks to first lactation. Sci. Rep. 7:40864. https://doi.org/10.1038/ srep40864.

Falentin, H., L. Rault, A. Nicolas, D. S. Bouchard, J. Lassalas, P. Lamberton, J.-M. Aubry, P.-G. Marnet, Y. Le Loir, and S. Even. 2016. Bovine teat microbiome analysis revealed reduced alpha diversity and significant changes in taxonomic profiles in quarters with a history of mastitis. Front. Microbiol. 7:480. https://doi.org/ 10.3389 /fmicb. 2016.00480.

Faul, F., E. Erdfelder, A.-G. Lang, and A. Buchner. 2007. G*Power 3: A flexible statistical power analysis program for the social, behavioral, and biomedical sciences. Behav. Res. Methods 39:175-191. https://doi.org/10.3758/BF03193146.

Friendly, M. 2006. Data ellipses, HE plots and reduced-rank displays for multivariate linear models: SAS software and examples. J. Stat. Softw. 17:1-42.

Friman, M., H. Hiitiö, M. Niemi, J. Holopainen, S. Pyörälä, and H. Simojoki. 2017. The effect of a cannula milk sampling technique on the microbiological diagnosis of bovine mastitis. Vet. J. 226:57-61. https://doi.org/10.1016/j.tvjl.2017.07.003.

Ganda, E. K., R. F. Bisinotto, S. F. Lima, K. Kronauer, D. H. Decter, G. Oikonomou, Y. H. Schukken, and R. C. Bicalho. 2016. Longitudinal metagenomic profiling of bovine milk to assess the impact of intramammary treatment using a third-generation cephalosporin. Sci. Rep. 6:37565. https://doi.org/10.1038/srep37565.

Guarín, J. F., C. Baumberger, and P. L. Ruegg. 2017. Anatomical characteristics of teats and premilking bacterial counts of teat skin swabs of primiparous cows exposed to different types of bedding. J. Dairy Sci. 100:1436-1444. https://doi.org/10.3168/jds.2016-11514.

Hiitiö, H., H. Simojoki, P. Kalmus, J. Holopainen, S. Pyörälä, and S. Taponen. 2016. The effect of sampling technique on PCRbased bacteriological results of bovine milk samples. J. Dairy Sci. 99:6532-6541. https://doi.org/10.3168/jds.2015-10811.

Hogan, J. S., K. L. Smith, K. H. Hoblet, D. A. Todhunter, P. S. Schoenberger, W. D. Hueston, D. E. Pritchard, G. L. Bowman, L. E. Heider, B. L. Brockett, and H. R. Conrad. 1989. Bacterial counts in bedding materials used on nine commercial dairies. J. Dairy Sci. 72:250-258. https://doi.org/10.3168/jds.S0022 -0302(89)79103-7.

Hogan, J. S., S. L. Wolf, and C. S. Petersson-Wolfe. 2007. Bacterial counts in organic materials used as free-stall bedding following treatment with a commercial conditioner. J. Dairy Sci. 90:10581062. https://doi.org/10.3168/jds.S0022-0302(07)71592-8.

Holt, H. M., B. Gahrn-Hansen, and B. Bruun. 2005. Shewanella algae and Shewanella putrefaciens: Clinical and microbiological characteristics. Clin. Microbiol. Infect. 11:347-352. https://doi.org/10 $.1111 /$ j.1469-0691.2005.01108.x.

Iulia, L., I. M. Bianca, O. Cornelia, and P. Octavian. 2013. The evidence of contaminant bacterial DNA in several commercial Taq polymerases. Rom. Biotechnol. Lett. 18:8007-8012.

Jervis-Bardy, J., L. E. X. Leong, S. Marri, R. J. Smith, J. M. Choo, H. C. Smith-Vaughan, E. Nosworthy, P. S. Morris, S. O'Leary, G. B. Rogers, and R. L. Marsh. 2015. Deriving accurate microbiota profiles from human samples with low bacterial content through post-sequencing processing of Illumina MiSeq data. Microbiome 3:19. https://doi.org/10.1186\%2Fs40168-015-0083-8.

Kozich, J. J., S. L. Wescott, N. T. Baxter, S. K. Highlander, and P. D. Schloss. 2013. Development of a dual-index sequencing strategy and curation pipeline for analyzing amplicon sequence data on the
MiSeq Illumina sequencing platform. Appl. Environ. Microbiol. 79:5112-5120. https://doi.org/10.1128/AEM.01043-13.

Kuehn, J. S., P. J. Gorden, D. Munro, R. Rong, Q. Dong, P. J. Plummer, C. Wang, and G. J. Phillips. 2013. Bacterial community profiling of milk samples as a means to understand culture-negative bovine clinical mastitis. PLoS One 8:e61959. https://doi.org/10 .1371/journal.pone.0061959.

Lima, S. F., A. G. V. Teixeira, F. S. Lima, E. K. Ganda, C. H. Higgins, G. Oikonomou, and R. C. Bicalho. 2017. The bovine colostrum microbiome and its association with clinical mastitis. J. Dairy Sci. 100:3031-3042. https://doi.org/10.3168/jds.2016-11604.

National Mastitis Council. 1999. Laboratory Handbook on Bovine Mastitis. National Mastitis Council, Verona, WI.

Oikonomou, G., M. L. Bicalho, E. Meira, R. E. Rossi, C. Foditsch, V. S. Machado, A. G. V. Teixeira, C. Santisteban, Y. H. Schukken, and R. C. Bicalho. 2014. Microbiota of cow's milk: Distinguishing healthy, sub-clinically, and clinically diseased quarters. PLoS One 9:e85904. https://doi.org/10.1371/journal.pone.0085904.

Oikonomou, G., V. S. Machado, C. Santisteban, Y. H. Schukken, and R. C. Bicalho. 2012. Microbial diversity of bovine mastitic milk as described by pyrosequencing of metagenomics $16 \mathrm{~s}$ rDNA. PLoS One 7:e47671. https://doi.org/10.1371/journal.pone.0047671.

Premalatha, N., N. O. Gopal, P. A. Jose, R. Anandham, and S.-W. Kwon. 2015. Optimization of cellulase production by Enhydrobacter sp. ACCA2 and its application in biomass saccharification. Front. Microbiol. 6:1046.

Quast, C., E. Pruesse, P. Yilmaz, J. Gerken, T. Schweer, P. Yarza, J. Peplies, and F. O. Glöckner. 2013. The SILVA ribosomal RNA gene database project: Improved data processing and web-based tools. Nucleic Acids Res. 41:D590-D596. https://doi.org/10.1093/ nar/gks1219.

Rainard, P. 2017. Mammary microbiota of dairy ruminants: Fact or fiction? Vet. Res. 48:25. https://doi.org/10.1186/s13567-017-0429 -2 .

Rowbotham, R. F., and P. L. Ruegg. 2016. Bacterial counts on teat skin and in new sand, recycled sand, and recycled manure solids used as bedding in freestalls. J. Dairy Sci. 99:6594-6608. https:// doi.org/10.3168/jds.2015-10674.

Schloss, P. D., S. L. Westcott, T. Ryabin, J. R. Hall, M. Hartmann, E. B. Hollister, R. A. Lesniewski, B. B. Oakley, D. H. Parks, C. J. Robinson, J. W. Sahl, B. Stres, G. G. Thallinger, D. J. Van Horn, and C. F. Weber. 2009. Introducing mothur: Open-source, platform-independent, community-supported software for describing and comparing microbial communities. Appl. Environ. Microbiol. 75:7537-7541. https://doi.org/10.1128/AEM.01541-09.

Shivaji, S., M. K. Ray, G. S. Kumar, G. S. N. Reddy, L. Saisree, and D. D. Wynn-Williams. 1991. Identification of Janthinobacterium fividum from the soils of the islands of Scotia Ridge and from Antarctic peninsula. Polar Biol. 11:267-271.

Smalley, N. E., S. Taipale, P. De Marco, N. V. Doronina, N. Kyrpides, N. Shapiro, T. Woyke, and M. G. Kalyuzhnaya. 2015. Functional and genomic diversity of methylotrophic Rhodocyclaceae: Description of Methyloversatilis discipulorum sp. nov. Int. J. Syst. Evol. Microbiol. 65:2227-2233. https://doi.org/10.1099/ijs.0.000190.

Staley, J. T., R. L. Irgens, and D. J. Brenner. 1987. Enhydrobacter aerosaccus gen. nov., sp. nov. a gas-vacuolated, facultatively anaerobic, heterotrophic rod. Int. J. Syst. Bacteriol. 37:289-291. https://doi.org/10.1099/00207713-37-3-289.

University of Wisconsin-Madison. 2017. Weather records. Accessed Sep. 27, 2017. http://marshfield.ars.wisc.edu/weather-records/.

Weaver, S. R., A. S. Prichard, N. L. Maerz, A. P. Prichard, E. L. Endres, L. E. Hernández-Castellano, M. S. Akins, R. M. Bruckmaier, and L. L. Hernandez. 2017. Elevating serotonin pre-partum alters the Holstein dairy cow hepatic adaptation to lactation. PLoS One 12:e0184939. https://doi.org/10.1371/journal.pone.0184939.

Weiss, S., Z. Z. Xu, S. Peddada, A. Amir, K. Bittinger, A. Gonzalez, C. Lozupone, J. R. Zaneveld, Y. Vázquez-Baeza, A. Birmingham, E. R. Hyde, and R. Knight. 2017. Normalization and microbial differential abundance strategies depend upon data characteristics. Microbiome 5:27. https://doi.org/10.1186/s40168-017-0237-y. 